\title{
Value of Local Wisdom in the Pillars of Cianjur Culture
}

\author{
Dina Indriyani ${ }^{1, *}$, Kokom Komalasari $^{2}$, Elly Malihah $^{3}$, Susan Fitriasari ${ }^{4}$ \\ 1,2,3,4 Universitas Pendidikan Indonesia, Bandung, Indonesia \\ ${ }^{*}$ Corresponding author.Email: dinaindriyani08@upi.edu
}

\begin{abstract}
Indonesia has a variety of local wisdom that lives and develops in the community. Local wisdom that lives and develops in the community is formed through a long and crystallized process in the form of customary law, belief and culture. Therefore, local wisdom can be interpreted as a norm that is practiced in society that is trusted and believed by the community so that it is used as a reference in everyday life. Local wisdom is an important part of society, especially in building human dignity in society. One of the local wisdoms that live and develop in Indonesia is the Pillars of Cianjur Culture which serves as the philosophy of life for the Cianjur people. Pillars of Cianjur Culture, consisting of Ngaos, Mamaos, Maenpo, Tatanen, Tanghinas, Someah, Sauyunan. This research is a descriptive study that focuses on exploring the values of local wisdom contained in the Pillars of Cianjur Culture. This research is a qualitative research using interviews and observations as a data collection tool. The data analysis technique used is a qualitative data analysis technique from Milles and Hubermans. This research resulted in several formulations regarding the value of wisdom contained in the Pillars of Cianjur Culture as a philosophy of life. The Pillars of Cianjur Culture is full of wisdom values. There are several main wisdom values contained in the Pillars of Cianjur Culture, including religious values, beauty values, toughness values, environmental protection values, dexterity and tenacity values, politeness values, and mutual cooperation values. With this research, it is hoped that it can be used as a reference for the government as policy makers to make a policy in an effort to preserve the local culture of the Pillars of Cianjur Culture.
\end{abstract}

Keywords: Local Wisdom, Local Wisdom Value, Pillars of Cianjur Culture.

\section{INTRODUCTION}

Globalization is an inevitable phenomenon today. Globalization has made the world seamless. [1]. Globalization makes it easy for countries in the world to interact with each other without any territorial boundaries that prevent it. [2]. The emergence of globalization has brought various impacts on people's lives in the world, Indonesia is no exception. Globalization has triggered the development of science and technology which is very significant in order to facilitate people's lives. However, the presence of globalization still has a negative impact on people's lives [3].

Globalization which is often accompanied by modernization and westernization has changed the order of people's lives. Modernization makes Indonesian society more hedonistic and consumptive. Meanwhile, westernization has resulted in Indonesian people being more westernized and tending to forget the cultural roots of their own country, especially local culture. The younger generation of Indonesia thinks that local culture is ancient so it deserves to be abandoned and they turn to cultures from other countries which they consider more modern.

Various social crises caused by changes in the order of Indonesian people's lives after globalization must be handled immediately. Because it is feared that it will threaten the existence of local values that live in institutions in the midst of Indonesian society. For this reason, it is time for countries in the world, especially Indonesia, to start reviving the local strength of the nation. The local strength possessed by a nation is a reminder and reinforcement for the sustainability of the nation's existence in the midst of globalization [4].

One of the local strengths possessed by a nation is local wisdom. Local wisdom as a society's view of life 
is full of the wisdom values contained in it. These wisdom values will become a filter to filter out the negative impacts caused by globalization. Therefore, the values of wisdom contained in various forms of local wisdom possessed by the Indonesian people must continue to be preserved so that they can still live institutionally in society from generation to generation. By institutionalizing the values of wisdom contained in various forms of local wisdom possessed by the Indonesian people, it is expected to be able to dispel all forms of negative impacts from globalization so that the existence of the Indonesian people in the midst of the world can be maintained.

This study describes some of the values contained in one of the local wisdoms in Indonesia, namely the Pillars of Cianjur Culture.

\section{THEORETICAL REVIEW}

In the cultural theory proposed by Kluckhon, it is stated that the culture created is a guide for people to behave [5]. Gerrtz (1973) suggests that local wisdom has an important meaning in people's lives, especially in maintaining human dignity in society [6] [7].

Various terms are used to refer to local wisdom. local wisdom, local knowledge, local genius [8], indigenous wisdom, traditional wisdom, and indigenous inventions [9], indigenous knowledge [10]. Etymologically, local wisdom comes from the word local which means local or a certain area and wisdom which means wisdom. Wisdom can be interpreted as the ability of an individual to respond or respond to something that is happening around him based on his thoughts and senses. While local means a space where an event occurs.

Local wisdom is defined as knowledge that functions as a view of life owned by a community. Local wisdom is one of the references or strategies used by the community to overcome the problems it faces as members of a community. [11]. Local wisdom is the crystallization of local local culture that has positive values. The form of local wisdom can be in the form of knowledge systems, social systems, value systems and cultural systems. Local wisdom is the pinnacle of cultural excellence which is the main identity of the nation [12]. Local wisdom as the capital of the nation's strength in the era of globalization has the following advantages: 1) has resistance to the onslaught of foreign cultures; able to survive against foreign cultures; 2) able to accommodate elements of foreign culture; 3) able to integrate elements of foreign culture into the original culture; 4) have good controllability; 5) can be a guide for cultural development [13]. Local wisdom is full of the wisdom values contained in it. Wisdom values that serve as guidelines in behaving and acting in social life.

From a philosophical point of view, local wisdom is defined as a set of knowledge that lives and develops in the local community. Local wisdom that develops in the community should be empirical and pragmatic. A local wisdom is empirical because it should be managed by the local community and assembled on real phenomena that occur in the local community. While a local wisdom can be pragmatic because it should be a local wisdom contained in a community can function as a means of solving problems faced by people everyday [14].

\section{METHODS}

The research method used in this research is descriptive analysis method using a qualitative approach. Data collection techniques used in this study were interviews and observation. Interviews were conducted with cultural leaders in Cianjur and the Cianjur Cultural Institute. While observations were made on related documents and made observations at art associations and art hermitages in accordance with the required data. After the necessary data is collected, the next step is to analyze the data. The data analysis technique used in this study is a qualitative data analysis technique from Miles and Huberman [15]. The qualitative data analysis technique of Milles and Hubermans consists of: a) data reduction; b) display data; and c) conclusion [16].

\section{RESULT AND DISCUSSIONS}

The Pillar of Cianjur Culture is the philosophy of Cianjur culture that lives in the Cianjur community. The Pillars of Cianjur Culture consist of seven cultural pillars that support the lives of Cianjur residents. The three main pillars are Nagos, Mamaos, and Maenpo. And the four main pillars, which consist of Tatanen, Tanghinas, Someah, and Sauyunan [17]

Ngaos which means the recite Al Quran. Mamaos is a singing culture that symbolizes subtlety. Mamaos is contained in the form of beautiful poems full of life values which are manifested in the form of the Tembang Cianjuran. Mamaos is the traditional art of singing/ngawih Tembang Sunda Cianjuran. Maenpo is a type of pencak silat martial art. This Maenpo tradition is a Sundanese martial arts tradition in order to form a tough human being. Tatanen is a community farming habit. Tanghinas can be interpreted as agile or agile, which is a condition of people who are quick to take action. Someah means polite, smiling. Sauyunan can be interpreted as mutual cooperation. In this Pillar of Cianjur Culture, various values of the character of the Cianjur people are stored which are extraordinary and very suitable if applied in the current era of globalization.

The local wisdom of the Pillars Cianjur Culture is full of wisdom values that are useful as a way of life [18] for the Cianjur people. The value of wisdom contained in the Pillars of Cianjur Culture can be used as social capital [19] in building the character of the Cianjur people who are more civilized and dignified. Based on 
the results of the analysis of the Pillars Cianjur Culture, various values of wisdom contained in the Pillars of Cianjur Culture are obtained, including religious values, beauty values, toughness values, environmental protection values, dexterity and tenacity values, politeness values, and mutual cooperation values.

In this Ngaos tradition, it describes how the relationship between humans and their creator is manifested by their love for the holy verses that have been revealed by Allah SWT which is manifested in the habit of reading the Al Quran. The Ngaos tradition is able to describe the condition of the religious Cianjur society [20]. Therefore, the main wisdom value contained in this Ngaos tradition is the high value of religiosity. The poems in the Tembang Cianjuran song also not only describe worldly beauty but also describe our gratitude to God Almighty [21 Aprilla]. The value of wisdom contained in Mamaos local wisdom is the value of cultured wisdom, gentle and glorifies God. In the martial art of maenpo, the knowledge of Liliwatan (avoidance) and Peupeuhan (blow) is known [22]. If a fighter has mastered this knowledge, he can be sure to have a good spirit of self-control [23]. The wisdom values contained in the Maenpo philosophy are the values of persistence, unyielding, and mental resilience. Tatanen is derived from tanen which means to plant rice. Tatanen can also be interpreted as farming. The wisdom values contained in the Tatanen philosophy are the values of persistence, patience, independence, and sincerity. Tanginas can be interpreted as an attitude that shows alertness, dexterity, accuracy in acting. Tanginas is the embodiment of an unyielding hard work attitude. The wisdom values contained in the Tanginas philosophy are swift, agile, and disciplined [24]. Someah is a form of attitude which in Indonesian can be interpreted as friendly. The value of wisdom contained in Someah's philosophy is the value of friendliness, politeness, gentleness, and kinship. Sauyunan has the meaning of togetherness. The concept of sauyunan must continue to be developed in the Millennial era as it is today. The era in which this noble togetherness is increasingly rare in a society that tends to be more individualistic. The value of wisdom contained in the Sauyunan philosophy is the value of mutual cooperation, togetherness, peace, and harmony.

The Pillars of Cianjur Culture also contains character values that can be used as capital for the development of culture-based character education. The character values contained in the Pillars of Cianjur Culture are as follows:

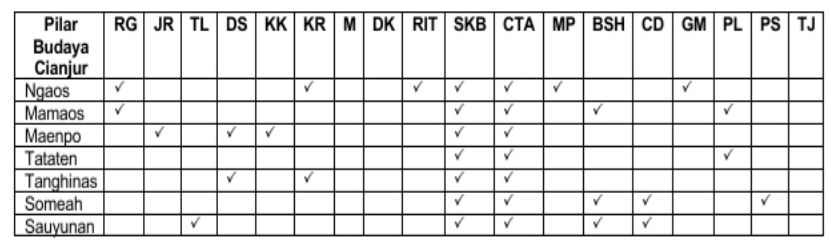

Note: Religious (RG), Honest (JR), Tolerance (TL), Discipline (DS), Hard Work (KK), Creative (KR) Independent (M), Democratic (DK), Curiosity (RIT), National Spirit (SKB), Nasionalism (CTA), Respect for Achievement (MP), Friendly / Communicative (BSH), Love Peace (CD), Love to Read (GM), Care for the Environment (PL), Care for Social (PS), Responsibility (TJ).

Figure 1. Character values in Pillars of Cianjur Culture.

From the figure, it is illustrated that the Pillars of Cianjur Culture contains several character values that are in accordance with the moral values of students developed by the government through the Character Education Development Program. The Pillars of Cianjur Culture contains character values that are religious values, honest, tolerance, discipline, hard work, creative, independent, democratic, curiosity, national spirit, nationalism, respect for achievement, friendly/communicative, love peace, love to read, care for the environment, care for social, and responsibility several main wisdom values contained in the Pillars of Cianjur Culture, including religious values, beauty values, toughness values, environmental care values, dexterity and tenacity values, politeness values, and mutual cooperation values. In addition, the Cianjur Cultural Pillar also contains character values that are in accordance with the Character Education Development

Program, namely religious values, honest, tolerance, discipline, hard work, creative, independent, democratic, curiosity, national spirit, nationalism, respect for achievement, friendly or ommunicative, love peace, love to read, care for the environment, care for social, and responsibility [25].

Based on the values developed through the cultural education program and the character of the nation, the values contained in the Pillars of Cianjur Culture can be described, as follows: 1) in the Ngaos pillar there are religious values, creative values, curiosity values, national spirit, love of homeland, appreciate achievement, and love to read; 2) in the pillars of Mamaos there are religious values, values of national spirit, values of love of homeland, values of friendship, and values of caring for the environment; 3 ) in the pillars of Maenpo there are values of honesty, values of discipline, values of hard work, values of national spirit, and values of love of homeland; 4) in the pillars of Agriculture there are values of national love, values of love of homeland, and values of caring for the environment; 5) in the pillars of Tanghinas are contained values of discipline, creative values, values of national spirit, and values of love of homeland; 6) in the pillars of Someah are contained the values of national spirit, the value of love of homeland, the value of friendship, the value of love of peace, and the value of social caring; and 7) in the pillars of Sauyunan are contained the values 
of tolerance, the values of national spirit, the values of love of homeland, the values of friendship, and the values of love of peace. From the description, it is clear that the Pillars of Cianjur Culture is loaded with values that need to be developed in accordance with the values contained in the Cultural Education and the Character of the Nation.

\section{CONCLUSION}

This research is in several formulations regarding the value of wisdom contained in the Pilars of Cianjur Cultures as a philosophy of life. The Pilars of Cianjur Culture is full of wisdom values. The results of this study are expected to be used as a basis for further researchers to conduct research on efforts to preserve the wisdom values contained in the Pillars of Cianjur Culture. With the results of this research, it is also hoped that policy makers in Cianjur Regency in particular can make a policy related to the preservation of this Pillars of Cianjur Culture.

\section{AUTHORS CONTRIBUTIONS}

All authors in this article have contributed according to their respective duties and functions.

\section{ACKNOWLEDGMENTS}

The author expresses his gratitude to the Cianjur Cultural Institute for providing the data that the authors need in this study. The author also expresses deep gratitude to all those who have provided assistance so that this research can be carried out.

\section{REFERENCES}

[1] J. D. Lewandowski , "Disembedded Democracy? Globalization and the 'Third Way'," European Journal of Social Theory, pp. 115131, 2003.

[2] A. Giddens, The Consequences of Modernity, Stanford: Polity Press, 1990.

[3] W. I. Robinson, "Globalization and the sociology of Immanuel Wallerstein: A critical appraisal," International Sociology, pp. 723745, 2011.

[4] T. Flew, "Globalization, neo-globalization and post-globalization: The challenge of populism and the return of the national," Global Media and Communication, pp. 1-21, 2020.

[5] A. L. Kroeber and C. Kluckhohn, Culture a Critical Review of Concepts and Definitions, New York: Vintage Book, 1963.

[6] C. Geertz, The Interpretation of Cultures, New York : Basic Book Inc Publishers, 1973.
[7] V. R. Vitasurya, "Local Wisdon for Sustainable Development of Rural Tourism,Case on Kalibiru and Lopati Vilage, Province of Daerah Istimewa Yogyakarta," Procedia-Social and Behavioral Sciences, pp. 97-108, 2015.

[8] U. Fajarini, "Peranan Kearifan Lokal Dalam Pendidikan Karakter," Sosio Didaktika, pp. 123130, 2014.

[9] National Innovation Foundation , "National Innovation Foundation Annual Report 20082009," National Innovation Foundation, Ahmedabad, 2009.

[10] E. Maryani and A. Yani, "Kearifan Lokal Masyarakat Sunda Dalam Memitigasi Bencana dan Aplikasinya Sebagai Sumber Pembelajaran IPS Berbasis Nilai," Jurnal Penelitian Pendidikan, pp. 114-125, 2014.

[11] Suparmini, S. Setyawati and D. R. S. Sumunar, "Pelestarian Lingkungan Masyarakat Baduy Berbasis Kearifan Lokal," Jurnal Penelitian Humaniora, pp. 8-22, 2013.

[12] E. Maryani, Modal Sosial Sebagai Pemersatu Bangsa, Makalah Seminar nasional IPS, 2008.

[13] Ayatrohaedi, Kepribadian Budaya Bangsa, Jakarta: Pustaka Jaya, 1986.

[14] D. Hidayat, "Permainan Tradisonal dan Kearifan Lokal Kampung Dukuh Garut Selatan Jawa Barat," Jurnal Academica , pp. 1057-1070, 2013.

[15] M. B. Miles and A. M. Huberman, Analisis Data Kualitatif Buku Sumber Tentang MetodeMetode Baru, Jakarta: UI Press, 2009.

[16] M. B. Miles and A. M. Huberman, Qualitative Data Analysis: an expanded sourcebook, California: Sage Publication, Inc., 1994.

[17] I. Ristiani, "Menjunjung Kearifan Budaya Cianjur sebagai Upaya Memperkuat Bahasa dan Budaya Sunda dalam Pemertahanan Karakter Bangsa," SIPATOHEANAN: South-East Asian Journal for Youth, SPort \& Health Education, pp. 15-30, 2019.

[18] D. Indriyani , "Urgency Value of Local Awareness Pillars of Cianjur Culture in Forming a Community 5.0," in International Conterence on Educational of Suryakancana, Cianjur, 2021.

[19] P. Bourdieu, "The Form of Capital," in Handbook of Theory and Research for the Sociology of Education, New York, Greenwood Press, 1986, pp. 241-258.

[20] G. Carel, R. Sugiarni, E. Algifari and H. Yastrib, "Implementasi Pilar-Pilar Budaya Cianjur dalam Pembelajaran Multiliterasi Matematis Berbantuan Teknologi Smartphone (Geogebra versi android) Untuk Meningkatkan Kemampuan Higher Order Thinking Skill (HOTS) Siswa Sekolah Kejuruan," Prisma, pp. 70-81, 2018. 
[21] A. Adawiyah and F. M. Munsi, "Character Values Represented in Tembang Sunda Cianjuran," Indonesia Language Education and Literature, pp. 1-16, 2019.

[22] R. A. Asy'arie, Silat Tradiisional Maenpo Cikalong R.H.O. Soleh Panduan Praktis Dasar Maenpo Cikalong, Bandung: PT. Mizan Pustaka, 2014.

[23] R. A. Asy'arie, Silat Tradisional Maenpo Cikalong Gan Uweh, Bandung: PT. Mizan Pustaka, 2013.

[24] Inayah Sarah and R. Sugiarni, "Effectiveness of Student Worksheets on Environmental ProjectBased e-learning Model in Building student Character," Journal of Physics, pp. 1-7, 2020.

[25] Badan Penelitian dan Pengembangan Pusat Kurikulum, Bahan Pelatihan Penguatan Metodologi Pembelajaran Berdasarkan NilaiNilai Budaya Untuk Membentuk Daya Saing dan Karakter Bangsa, Jakarta: Kementerian Pendidikan Nasional, 2010. 